Running Head : A SYSTEMATIC REVIEW ON SECOND LANGUAGE ACQUISITION

Learning by Doing : A Systematic Review on Second Language Acquisition Corresponding to Personality

\title{
Traits
}

Mrs. Malabika Tripathi**, Ria Dutta*, Akanksha Roy*, Malvika Sah*

**Assistant Professor, *Graduation Student

Department of Applied Psychology, Amity University Kolkata 
Running Head: A SYSTEMATIC REVIEW ON SECOND LANGUAGE ACQUISITION

\begin{abstract}
INTRODUCTION: Considering the significant amount of world population, there is a huge section of people who are bilingual or multilingual. On the other hand, many people do not have the knowledge or understanding of second language. Personality traits and along with individual differences play a huge role in second language acquisition. Every individual is unique and hence their way of learning or developing a completely new skill varies significantly.
\end{abstract}

OBJECTIVES: The objectives of this paper were to explore how Second Language Acquisition (SLA) is related to various personality traits and to explore this relationship in terms of bi-directional link between the two.

METHOD: The method of literature review was employed.

FINDINGS: The findings of the present study indicate personality traits, motivation levels and perception of one's self, other native speakers and of the language have a bi-directional relationship with SLA. Every individual approaches the SLA process differently and has a different success rate with it. It has also been hypothesised that music aids in understanding sound structure and in turn facilitates SLA. We further discuss how socio-cultural factors may play a role here.

CONCLUSION: One of the main points that can be drawn from the present study is that SLA is mainly a matter of perception i.e., it is dependent on how an individual choses to view it. According to the demands of the $21^{\text {st }}$ century, more language-oriented activities should be incorporated to make second language learning (SLL) an intellectually stimulating process. Additionally, we believe that there exists a bi-directional relationship between personality traits and SLA. Future directions for future researches are also suggested.

Keywords: Bilingualism, Individual differences, OCEAN, Personality, Second Language Acquisition. 
Running Head : A SYSTEMATIC REVIEW ON SECOND LANGUAGE ACQUISITION

\section{A Review on Second Language Acquisition Corresponding to Personality Traits}

A significant amount of people in the world are bilingual and multilingual today but many others still do not and only yearn for having the ability and knowledge of a second language (L2). Learning a language other than your first one comes with its own set of difficulties.

When talking about Second Language Acquisition (SLA), the first question which needs to be answered is "What is the distinction between 'acquisition' and 'learning'?" 'Acquisition' happens more subconsciously, and here the main focus remains on communication and meaning of the language (Schutz, 1998). We can say that acquisition happens in an informal environment. We hear the language from our surrounding and are able to speak and understand it, rather like small children. 'Learning', on the other hand, is more theoretical, the emphasis is more on learning and retaining grammar, syntax rules, and vocabulary, etc. A point to be noted here is that learning doesn't necessarily mean that a person will be able to speak and converse fluently (Gordon, 2000).

While learning a language, many factors have a significant role to play - i.e. these factors can be Internal or External (Macaro, 2013). Internal factors are those that come with the person as they begin to learn a language, they are different for every individual. Age as an internal factor shows that children who have solid literacy skills from a young age can learn a language more easily (Penfield, 1965). Similarly, personality types such as extroverts have a better time learning and interacting as compared to their introvert counterparts. Internal factors also include intrinsic motivation, experience, cognition and native language experiences. Internal drive and willingness to learn will enable a person to take pride as they progress in their learning (Coker and Mihai, 2017; Mahmoodi and Moazam, 2014). Previous experiences with the language or some knowledge of it enables better progress and understanding. It has also been observed that children will higher 
cognitive abilities will excel more in language learning (Penfield, 1965). Additionally, researches have stated that the native language or the first language will impact the learning of a new language. For example- a person

whose native language is English will face less difficulty in learning Spanish as compared to a person whose native language is Japanese (Lightbown \& Spada., 2013).

External factors depend on the situation. Curriculum, instructions, extrinsic motivation, culture and status, and experiences with native speaker(s) will have some influence on the language learning process. The teaching methods and classroom activities centered on interactions and engagements are best if designed according to student's needs (Schwartz, Deeb \& Hijazy 2019). While learning if the medium of conversation and instructions is shifted to the language being taught, can facilitate the learning process, similarly frequent exposure to communication and native speakers gives an idea about correct pronunciation, vocabulary and most importantly, the colloquiality of the target language. Lastly, encouraging the student and keeping them motivated to learn will show better signs of progress.

Over the decades extensive researches have been done to see the relationship between personality and SLA and Bilingualism. Personality has been defined in a number ways through ages. According to Weinberg \& Gould (1999), personality can be defined as "the characteristics or blend of characteristics that make a person unique" (Saul McLeod, 2017). People have different personalities, different traits and characteristics that mark humans different from each other. As personality traits make us all different, Individual Differences (I.Ds) can be potential factor to study to understand that I.Ds can also influences language learning. Cluster of traits together might have some influence on SLA (Dörnyei, 2006). As we defined personality, it is also important to know what SLA and Bilingualism is. 
SLA is defined as the learning and adopting of a language that is not one's native language (Zhang, 2008). When a person acquires a second language, they aim to master the ability to speak and understand that target language fluently. SLA process is also extended to learning third, fourth, fifth languages and so on. Bilingualism on the other hand is the ability to speak two or more languages (Elizabeth, 2009). Many people around the globe speak multiple languages. In our own country India, most of our population speaks their native

language, Hindi and English. A number of theories hold that personality factors into account state that they can significantly influence the degree of success that individuals achieve in learning a second language (Gass \& Selinker, 1994) based on the assumption that some features of the learner's personality might encourage or inhibit second language learning (Cook, 1996) by enhancing certain facets of language learning while impeding others (Larsen-Freeman \& Long, 1991; Zhang 2008).

In this paper we try to review as many researches as possible done in the domain of SLA with its relation to personality and we try to investigate the bi-directionality of the relationship between personality traits and SLA is. In other words, we try to understand how personality traits can be a facilitator or predictor to SLA and how SLA affects the personality of an individual.

\section{Literature Review}

There has been a fixed notion that personality is a fixed construct that is resistant to change if it is once fixed. However recent literatures and researches have report that personality traits can be changed or influenced by certain factors adhering to the interplay of both situation and one's own maturation (Lanning et al., 2018). Language learning is a potential factor that may lead to personality change. In this study, we try to explore the bi-directional nature of personality traits influencing SLA process of an individual and how they are also influenced by the SLA process itself. 
Stephen Krashen, an expert in the field of linguistics, propounded a theory which consists of five hypotheses. Among the five, the "Acquisition-Learning hypothesis" is the most widely known among linguists, experts and language teachers. It was Krashen's theory that brought into limelight the fine distinction between "learning" and "acquisition"; the "learned system" and the "acquired system". Krashen defines learning to be of less importance than acquiring because learning is a conscious process which results in the conscious acknowledgement of the language (Schutz, 1998). It is the product of formal instructions like teaching materials and instructions. On the other hand, acquisition is emphasized because it is the subconscious process that

\section{Running Head : A SYSTEMATIC REVIEW ON SECOND LANGUAGE ACQUISITION}

requires meaningful interaction of the target language (Schutz, 1998). It is the product of speaker's concentration and internalization of the target language. The Acquisition-Learning hypothesis represents not only the process of learning/acquiring the first language of individuals but also any others they wish to learn after their first. In this sense, the term "second" refers to not only the second language in terms of numeric but also third, fourth, fifth and so on.

A book written by Jane D. Hill and Cynthia L. Bjork (2013) state the five stages of second language acquisition (SLA) as shown below: 
Running Head : A SYSTEMATIC REVIEW ON SECOND LANGUAGE ACQUISITION

\section{The Five Stages of Second Language Acquisition:}

\begin{tabular}{|c|c|c|c|}
\hline Stage & Characteristics & $\begin{array}{l}\text { Approximate } \\
\text { Time Frame }\end{array}$ & Teacher Prompts \\
\hline Preproduction & $\begin{array}{l}\text { The student } \\
\text {-Has minimal comprehension. } \\
\text {-Does not verbalize. } \\
\text { Nods "Yes" and "No." } \\
\text { Draws and points. }\end{array}$ & $0-6$ months & $\begin{array}{l}\text {-Show me ... } \\
\text {-Circle the ... } \\
\text {-Where is ...? } \\
\text {-Who has ...? }\end{array}$ \\
\hline Early Production & $\begin{array}{l}\text { The student } \\
\text {-Has limited comprehension } \\
\text {-Produces one- or two-word responses. } \\
\text {-Uses key words and familiar phrases. } \\
\text {-Uses present-tense verbs. }\end{array}$ & 6 months - 1 year & $\begin{array}{l}\text {-Yes/no questions } \\
\text {-Either/or questions } \\
\text {-Who ...? } \\
\text {-What ...? } \\
\text { - How many ...? }\end{array}$ \\
\hline Speech Emergence & $\begin{array}{l}\text { The student } \\
\text {-Has good comprehension. } \\
\text {-Can produce simple sentences. } \\
\text {-Makes grammar and pronunciation errors. } \\
\text {-Frequently misunderstands jokes. }\end{array}$ & $1-3$ years & $\begin{array}{l}\text {-Why ...? } \\
\text {-How ...? } \\
\text {-Explain ... } \\
\text {-Questions requiring phrase or } \\
\text { short-sentence answers }\end{array}$ \\
\hline Intermediate Fluency & $\begin{array}{l}\text { The student } \\
\text {-Has excellent comprehension. } \\
\text {-Makes few grammatical errors. }\end{array}$ & $3-5$ years & $\begin{array}{l}\text {-What would happen if ...? } \\
\text {-Why do you think ...? } \\
\text {-Questions requiring more than a } \\
\text { sentence response }\end{array}$ \\
\hline Advanced Fluency & The student has a near-native level of speech. & 5-7 years & $\begin{array}{l}\text {-Decide if } \\
\text {-Retell ... }\end{array}$ \\
\hline
\end{tabular}

Note: Source: Classroom instruction that works with English language learners by Jane D. Hill and Cynthia L. Bjork (2013).

Since SLA is the internalization of a language, it can also be referred to as the implicit learning of L2. Another hypothesis, i.e. The Affective Filter Hypothesis, developed by Krashen is of relevance to this study. According to this hypothesis, there are number of affective variables that play a facilitating or an inhibiting role in the SLA process (Schutz, 2018). These affective variables include anxiety, motivation levels, self-confidence, openness to new things, explorative, open-mindedness, etc. To go by the widely known and used taxonomy of personality, the Five Factor Model incorporates all these affective variables.

Much of the researches in the domain of SLA focused upon the importance of motivation and aptitude of the learners. Some researches over the past years have tried to report the relationship between personality 
traits (under the taxonomy of OCEAN) and SLA process (Abali, 2006; Hu \& Reiterer, 2009; Kezwer, 1987; Larissa, Troesch \& Grob, 2013; Pourfeiz, 2015; Veltkamp et al., 2013). Robinson, Gabriel \& Katchan (1994) have tried to study the relationship between SLA and personality traits in terms of Eysenck's EPQ questionnaire with EPN domains. This study reported that all the 3 domains (i.e. Extraversion, Psychoticism and Neuroticism) correlated with both written and oral tests of SLA. Out of the 3 domains, Neuroticism was suggested to be caused by high levels of cerebral arousal, thus completing the intertwined structure of the Biopsychosocial Model. Studies exploring the relationship between personality traits and SLA have also been done on immigrants that reveal similar findings with the existing literature (Ozanska-Ponikwia \& Dewaele, 2012). Additional researches done also highlight further insights into the language development of children that may coincide with their personality development (Gordon, 2000; Paradis, 2007).

\section{Objectives of the study}

The main objective of the study is to explore the role of personality traits (influenced by other psycho-sociocultural factors) on the acquisition of a language that may help individuals, educational institutes and organizations get a holistic understanding of themselves or their candidates and tailor-fit their language learning or teaching programmes to the best of one's potentiality. In this context the present study extensively reviews the literatures available in this field to answer the research questions:

1. How are personality traits a predictor of language acquisition process of an individual?

2. How personality traits act as facilitators for the language acquisition of an individual?

3. How does SLA have an effect on one's personality?

The findings of this research would enable prospective researchers, professional and students to recognize the role and importance of personality traits when it comes to learning or acquiring a new language which can 
Running Head : A SYSTEMATIC REVIEW ON SECOND LANGUAGE ACQUISITION

remotely give new insights in this field and especially be helpful to the educational institutions to prepare their students for the future.

\section{Methodology}

\section{Framework of the Study and Adopted Research Approach}

This section explains the data that was chosen, including the method and critical insight, for conducting this study. This research investigates the role of personality factors (through the lens of Five Factor Model (OCEAN)) on the SLA process of an individual. Additionally, this study explores the role of motivational variables and other socio-cultural variables that comes into play in the SLA process.

Literature review is the foundation for this methodical inscription. Through proper literature review, the researcher gets appropriate and relevant knowledge about the "text and identifies the eminent authors" exploring the same domains (Ferenhof and Fernandes, 2016). The search for relevant research paper and books was done through Google Scholar, PubMed, ScienceDirect, ProQuest, and Semantic Scholar to get the maximum input to enrich the investigation. The key terms used were: 'Second Language Acquisition', 'Personality', 'Bilingualism', 'Individual differences', 'OCEAN', 'Language learning' and 'Language aptitude'. In stage 1 of the Scrutinization process, using the above-mentioned keywords, abstracts were analyzed to the understand the appropriateness of the research. In stage 2, inappropriate researches were removed by scanning entire manuscript, which lead to reach the final stage 3 where 60 papers were selected for further analysis. 


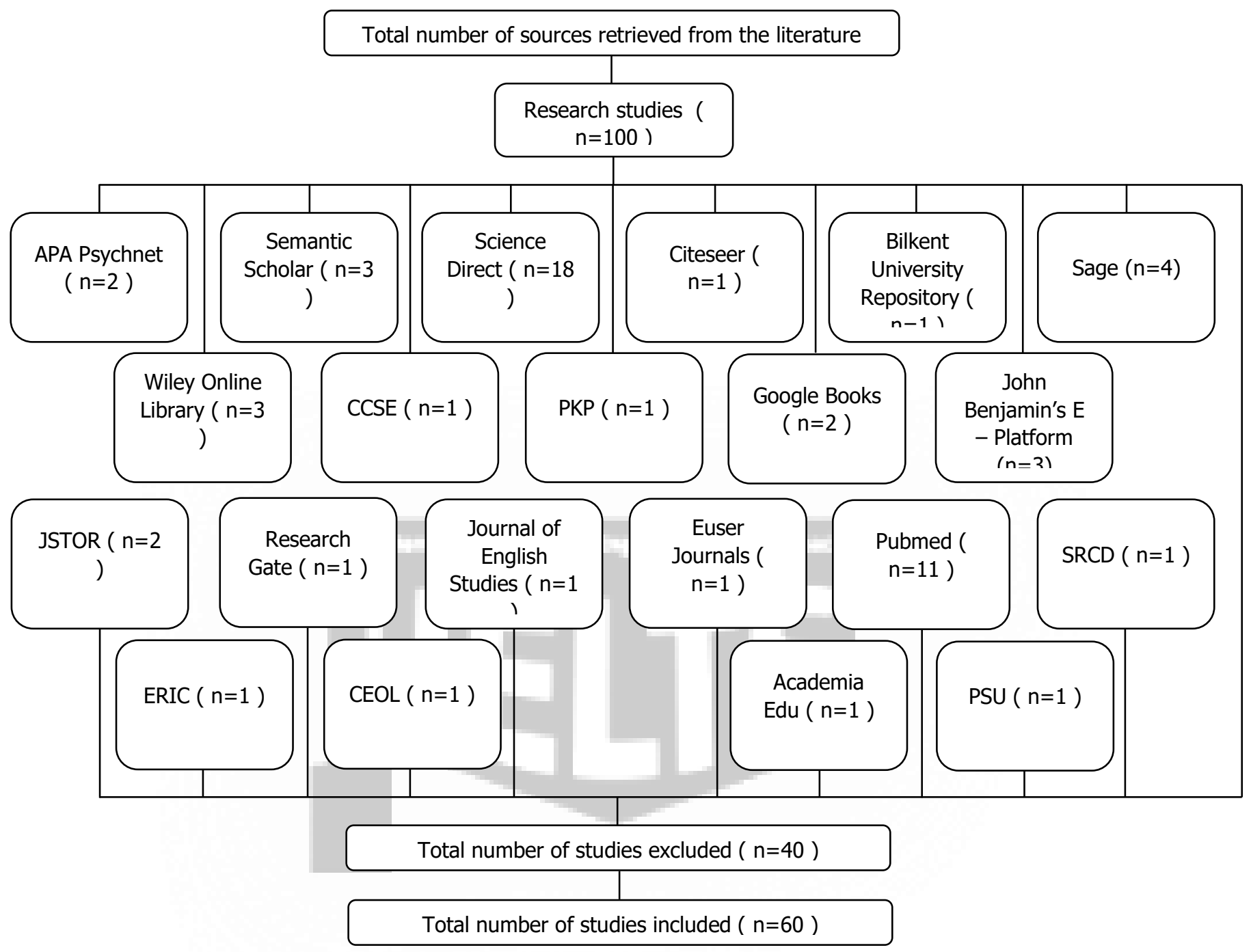

Note : A flow diagram representing the 100 studies retrieved from the existing published literature . A total of 60 studies were included in this study for further discussion. 
Running Head : A SYSTEMATIC REVIEW ON SECOND LANGUAGE ACQUISITION

\section{List of Finally Selected Researches}

\section{Table 1: Reviewed Literatures (Academic Research Articles):}

\begin{tabular}{|c|c|c|}
\hline $\begin{array}{l}\text { Sl. } \\
\text { No. }\end{array}$ & Literature & Aim \\
\hline 1. & $\begin{array}{l}\text { Lalonde, R. N., \& Gardner, R. C. (1984). Investigating a causal } \\
\text { model of second language acquisition: Where does personality } \\
\text { fit? Canadian Journal of Behavioural Science/Revue canadienne } \\
\text { des sciences du comportement, 16(3), } 224 \text {. }\end{array}$ & $\begin{array}{l}\text { To explore the role of personality variables } \\
\text { for second language acquisition (SLA); To } \\
\text { integrate personality variables into the } \\
\text { adapted version of Gardner's socio- } \\
\text { educational model. }\end{array}$ \\
\hline 2. & $\begin{array}{l}\text { Zhang, Y. (2008). The role of personality in second language } \\
\text { acquisition. Asian Social Science, } 4(5), 58-59 \text {. }\end{array}$ & $\begin{array}{l}\text { To examine and illustrate the relationship } \\
\text { between personality and SLA. }\end{array}$ \\
\hline 3. & $\begin{array}{l}\text { Keller, K., Troesch, L. M., \& Grob, A. (2013). Shyness as a risk } \\
\text { factor for second language acquisition of immigrant } \\
\text { preschoolers. Journal of applied developmental psychology, 34(6), } \\
\text { 328-335. }\end{array}$ & $\begin{array}{l}\text { To study whether shyness plays a role in the } \\
\text { SLA process in immigrant pre-schoolers. }\end{array}$ \\
\hline 4. & $\begin{array}{l}\text { Bialystok, E. (2006). Second-language acquisition and bilingualism } \\
\text { at an early age and the impact on early cognitive } \\
\text { development. Encyclopedia on early childhood development, 1-4. }\end{array}$ & $\begin{array}{l}\text { To study the impact of SLA and } \\
\text { Bilingualism on early cognitive } \\
\text { development of children. }\end{array}$ \\
\hline 5. & $\begin{array}{l}\text { Pourfeiz, J. (2015). Exploring the relationship between global } \\
\text { personality traits and attitudes toward foreign language } \\
\text { learning. Procedia-Social and Behavioral Sciences, 186, 467-473. }\end{array}$ & $\begin{array}{l}\text { To explore the relationship between global } \\
\text { personality traits and associated attitudes } \\
\text { towards learning a foreign language in a } \\
\text { Turkish context. }\end{array}$ \\
\hline 6. & $\begin{array}{l}\text { LoCastro, V. (2001). Individual differences in second language } \\
\text { acquisition: Attitudes, learner subjectivity, and L2 pragmatic } \\
\text { norms. System, 29(1), 69-89. }\end{array}$ & $\begin{array}{l}\text { To study the attitudes of English Foreign } \\
\text { Language learners in terms of individual } \\
\text { differences (i.e. relationship between } \\
\text { attitudes, learner self-identity and } \\
\text { willingness to conform to secondary } \\
\text { language (L2) pragmatic norms. }\end{array}$ \\
\hline 7. & $\begin{array}{l}\text { Abali, F. (2006). The effect of personality traits } \\
\text { extroversion/introversion on verbal and interactive behaviors of } \\
\text { learners (Doctoral dissertation, Bilkent University). }\end{array}$ & $\begin{array}{l}\text { The effect of personality traits } \\
\text { extroversion/introversion on learners' } \\
\text { communicative L2 behaviour. }\end{array}$ \\
\hline 8. & $\begin{array}{l}\text { MacIntyre, P. D., \& Charos, C. (1996). Personality, attitudes, and } \\
\text { affect as predictors of second language communication. Journal of } \\
\text { language and social psychology, 15(1), 3-26. }\end{array}$ & $\begin{array}{l}\text { To examine the impact of personality, } \\
\text { attitude on the frequency of second language } \\
\text { communication and also to examine the role } \\
\text { of global personality traits. }\end{array}$ \\
\hline 9. & Robinson, D., Gabriel, N., \& Katchan, O. (1994). Personality and & To study the relationship between \\
\hline
\end{tabular}




\begin{tabular}{|c|c|c|}
\hline & $\begin{array}{l}\text { second language learning. Personality and Individual } \\
\text { Differences, } 16(1), 143-157 .\end{array}$ & $\begin{array}{l}\text { personality differences and individual } \\
\text { differences in learning language ability. }\end{array}$ \\
\hline 10. & $\begin{array}{l}\text { Dewaele, J. M. (2012). Personality in second language } \\
\text { acquisition. The Encyclopedia of Applied Linguistics. }\end{array}$ & $\begin{array}{l}\text { To examine the link between personality } \\
\text { traits and SLA/L2. }\end{array}$ \\
\hline 11. & $\begin{array}{l}\text { Polat, B. (2013). Language experience interviews: What can they } \\
\text { tell us about individual differences? System, } 41(1), 70-83 \text {. }\end{array}$ & $\begin{array}{l}\text { To study the individual differences (IDs) } \\
\text { variables via top-down approach that starts } \\
\text { with understanding the students' language } \\
\text { learning experience. }\end{array}$ \\
\hline 12. & $\begin{array}{l}\text { Karim, N. A., Abidin, D. Z., \& Ali, S. N. D. M. (2016). } \\
\text { PERSONALITY FACTORS AND SECOND LANGUAGE } \\
\text { ACQUISITION: AN ISLAMIC VIEWPOINT. }\end{array}$ & $\begin{array}{l}\text { To study the role of individual personality } \\
\text { factors in a second language acquisition } \\
\text { process from an Islamic point of view. }\end{array}$ \\
\hline 13. & $\begin{array}{l}\text { Skellett, C. (2017). Assessing Introversion and Extroversion in a } \\
\text { Second Language Setting. }\end{array}$ & $\begin{array}{l}\text { To create a useful tool for assessing } \\
\text { personality in the language classroom by } \\
\text { testing a newly created personality test and } \\
\text { comparing it's results to a previously used } \\
\text { and well-known tool. }\end{array}$ \\
\hline 14. & $\begin{array}{l}\text { Oz, H., Demirezen, M., \& Pourfeiz, J. (2015). Emotional } \\
\text { intelligence and attitudes towards foreign language learning: } \\
\text { Pursuit of relevance and implications. Procedia-Social and } \\
\text { Behavioral Sciences, 186(0). }\end{array}$ & $\begin{array}{l}\text { To study the relationship between the } \\
\text { perceptions of Emotional Intelligence (EI) } \\
\text { and the attitudes one has towards learning a } \\
\text { foreign language in a Turkish context. }\end{array}$ \\
\hline 15. & $\begin{array}{l}\text { Lou, N. M., \& Noels, K. A. (2019). Promoting growth in foreign } \\
\text { and second language education: A research agenda for mindsets in } \\
\text { language learning and teaching. System, } 86,102126 \text {. }\end{array}$ & $\begin{array}{l}\text { To review the existing literature on the role } \\
\text { of mindsets in language education and } \\
\text { identify and fill research gaps. }\end{array}$ \\
\hline 16. & $\begin{array}{l}\text { Schwartz, M., Deeb, I., \& Hijazy, S. (2019). "Say 'What } \\
\text { happened?'in Hebrew. He does not speak Arabic!" Early language } \\
\text { awareness as expressed in verbal and nonverbal interactions in the } \\
\text { preschool bilingual classroom. Linguistics and Education,52,13-23. }\end{array}$ & $\begin{array}{l}\text { To study how children's verbal and non- } \\
\text { verbal behaviour from bilingual Isrealian } \\
\text { preschool reflectst their language awareness. }\end{array}$ \\
\hline 17. & $\begin{array}{l}\text { Sharp, A. (2008). Personality and second language learning. Asian } \\
\text { Social Science, 4(11), 17-25. }\end{array}$ & $\begin{array}{l}\text { To examines the relationships which exist } \\
\text { between personality and second language } \\
\text { learning and add on to the } \\
\text { data available on the use of a highly } \\
\text { respected personality indicator, the Myers } \\
\text { Briggs Type Indicator (MBTI). }\end{array}$ \\
\hline 18. & $\begin{array}{l}\text { Kezwer, P. (1987). The extroverted vs. the introverted personality } \\
\text { and second language learning. TESL Canada Journal, 45-58. }\end{array}$ & $\begin{array}{l}\text { To survey all the major studies dealing with } \\
\text { the influence of extroversion on second } \\
\text { language learning. }\end{array}$ \\
\hline 19. & $\begin{array}{l}\text { Nakamura, T. (2019). Understanding motivation for learning } \\
\text { languages other than English: Life domains of L2 self. System, } 82 \text {, } \\
\text { 111-121. }\end{array}$ & $\begin{array}{l}\text { To study the different domains of self with } \\
\text { respect to learning an L2 other than English. } \\
\text { To explore the future of L2 self-images of } \\
\text { Japanese students with regards to their } \\
\text { motivation levels. }\end{array}$ \\
\hline 20. & Economidou-Kogetsidis, M. (2016). Variation in evaluations of the & To study the differences between L2 \\
\hline
\end{tabular}




\begin{tabular}{|c|c|c|}
\hline & $\begin{array}{l}\text { (im) politeness of emails from L2 learners and perceptions of the } \\
\text { personality of their senders. Journal of Pragmatics, 106, 1-19. }\end{array}$ & $\begin{array}{l}\text { university students and English native } \\
\text { speaking (NS) teachers in terms of their } \\
\text { perception and evaluation of L2 direct and } \\
\text { unmodified student emails to faculty. }\end{array}$ \\
\hline 21. & $\begin{array}{l}\text { Oroujlou, N., \& Vahedi, M. (2011). Motivation, attitude, and } \\
\text { language learning. Procedia-Social and Behavioral Sciences, 29, } \\
\text { 994-1000. }\end{array}$ & $\begin{array}{l}\text { To determine whether there is an effective } \\
\text { and efficient relationship between language } \\
\text { learning, motivation and attitude. }\end{array}$ \\
\hline 22. & $\begin{array}{l}\text { MacIntyre, P. D., \& Blackie, R. A. (2012). Action control, } \\
\text { motivated strategies, and integrative motivation as predictors of } \\
\text { language learning affect and the intention to continue learning } \\
\text { French. System, } 40(4), 533-543 \text {. }\end{array}$ & $\begin{array}{l}\text { To study the relative ability of variables } \\
\text { from } 3 \text { motivational theories to predict } 4 \\
\text { non-linguistic outcomes of language } \\
\text { learning. }\end{array}$ \\
\hline 23. & $\begin{array}{l}\text { Mahmoodi, M. H., \& Moazam, I. (2014). Willingness to } \\
\text { communicate (WTC) and L2 achievement: The case of Arabic } \\
\text { language learners. Procedia-Social and Behavioral Sciences, 98, } \\
\text { 1069-1076. }\end{array}$ & $\begin{array}{l}\text { To study the relationship between WTC and } \\
\text { FL achievement of Arabic students. }\end{array}$ \\
\hline 24. & $\begin{array}{l}\text { Zarrinabadi, N. (2014). Communicating in a second language: } \\
\text { Investigating the effect of teacher on learners' willingness to } \\
\text { communicate. System, } 42,288-295 \text {. }\end{array}$ & $\begin{array}{l}\text { To study the effect of teachers on the } \\
\text { learner's tendency to talk in class. }\end{array}$ \\
\hline 25. & $\begin{array}{l}\text { Hu, X., \& Reiterer, S. (2009). Personality and pronunciation talent } \\
\text { in second language acquisition. Language talent and brain activity, } \\
97-130 .\end{array}$ & $\begin{array}{l}\text { To study the effect of personality and } \\
\text { pronounciation talent on second language } \\
\text { acquisition. }\end{array}$ \\
\hline 26. & $\begin{array}{l}\text { Dörnyei, Z. (2006). Individual differences in second language } \\
\text { acquisition. AILA Review, 19(1), 42-68. }\end{array}$ & $\begin{array}{l}\text { To study the effect of individual differences } \\
\text { in second language acquisition. }\end{array}$ \\
\hline 27. & $\begin{array}{l}\text { Grace M. H. Gayle. (1981). Personality, Motivation, and Second } \\
\text { Language Learning. Canadian Journal of Education / Revue } \\
\text { Canadienne De L'éducation, 6(3), 55-67. }\end{array}$ & $\begin{array}{l}\text { To assess how personality and motivation } \\
\text { plays a role in second language learning. }\end{array}$ \\
\hline 28. & $\begin{array}{l}\text { Obralic, N., \& Mulalic, A. (2017). Correlation between personality } \\
\text { traits and Language Learning Strategies among IUS } \\
\text { Students. Journal of Applied Linguistics and Language } \\
\text { Research, 4(5), 76-84. }\end{array}$ & $\begin{array}{l}\text { To assess Correlation between Personality } \\
\text { Traits and Language Learning Strategies } \\
\text { among IUS Students Almasa Mulalic. }\end{array}$ \\
\hline 29. & $\begin{array}{l}\text { Coker, C., \& Mihai, F. (2017). Personality traits and second } \\
\text { language acquisition: The Influence of the enneagram on adult } \\
\text { ESOL students. TESOL Journal, } 8(2), 432-449 \text {. }\end{array}$ & $\begin{array}{l}\text { To assess personality traits via the } \\
\text { Enneagram Profile to a group of } 10 \text { adult } \\
\text { advanced students of English for speakers of } \\
\text { other languages. }\end{array}$ \\
\hline 30. & $\begin{array}{l}\text { van Niejenhuis, C., Otten, S., \& Flache, A. (2018). Sojourners' } \\
\text { second language learning and integration. The moderating effect of } \\
\text { multicultural personality traits. International Journal of } \\
\text { Intercultural Relations, 63, 68-79. }\end{array}$ & $\begin{array}{l}\text { To examine the role of trainable intercultural } \\
\text { personality traits in the widely assumed link } \\
\text { between immigrants' second language (L2) } \\
\text { learning and their cultural integration in the } \\
\text { host country. }\end{array}$ \\
\hline 31. & $\begin{array}{l}\text { Y1lmaz, C. (2010). The relationship between language learning } \\
\text { strategies, gender, proficiency and self-efficacy beliefs: a study of } \\
\text { ELT learners in Turkey. Procedia-Social and Behavioral } \\
\text { Sciences, 2(2), 682-687. }\end{array}$ & $\begin{array}{l}\text { To study and explore the learning strategies } \\
\text { employed and preferred with respect to } \\
\text { gender, proeficiency and self-efficacy } \\
\text { beliefs. }\end{array}$ \\
\hline 32. & Veltkamp, G. M., Recio, G., Jacobs, A. M., \& Conrad, M. (2013). & To examine if personality is modulated by \\
\hline
\end{tabular}




\begin{tabular}{|c|c|c|}
\hline & $\begin{array}{l}\text { Is personality modulated by language? International Journal of } \\
\text { Bilingualism, } 17(4), 496-504 \text {. }\end{array}$ & language. \\
\hline 33. & $\begin{array}{l}\text { Moody, R. (1988). Personality preferences and foreign language } \\
\text { learning. The Modern Language Journal, 72(4), 389-401. }\end{array}$ & $\begin{array}{l}\text { To assess the personality preferences in } \\
\text { foreign language learning }\end{array}$ \\
\hline 34. & $\begin{array}{l}\text { Ozanska-Ponikwia, K., \& Dewaele, J. M. (2012). Personality and } \\
\text { L2 use: The advantage of being openminded and self-confident in } \\
\text { an immigration context. Eurosla Yearbook, 12(1), 112-134. }\end{array}$ & $\begin{array}{l}\text { To know unique psychological } \\
\text { characteristics that could predict the } \\
\text { frequency with which L2 users engage in L2 } \\
\text { interactions in context of immigrants. }\end{array}$ \\
\hline 35. & Paradis, J. (2007). Second language acquisition in childhood. & $\begin{array}{l}\text { To review researches of L2 learning in terms } \\
\text { of children and childhood. }\end{array}$ \\
\hline 36. & $\begin{array}{l}\text { Nikoopour, J., \& Amini Farsani, M. (2011). On the relationship } \\
\text { between language learning strategies and personality types among } \\
\text { Iranian EFL learners. Journal of English studies, 1(1), 81-101. }\end{array}$ & $\begin{array}{l}\text { To find out the kinds of language learning } \\
\text { strategies that Iranian EFL learners mostly } \\
\text { utilize. also, the language learning strategies } \\
\text { preferred by Iranian extrovert/introvert, } \\
\text { sensing/intuitive, thinking/feeling, and } \\
\text { judging/perceiving language learners are } \\
\text { also considered. }\end{array}$ \\
\hline 37. & $\begin{array}{l}\text { Granena, G., Jackson, D. O., \& Yilmaz, Y. (Eds.). } \\
\text { (2016). Cognitive individual differences in second language } \\
\text { processing and acquisition (Vol. 3). John Benjamins Publishing } \\
\text { Company. }\end{array}$ & $\begin{array}{l}\text { To investigate and study the relationship of } \\
\text { the working memory, personality and } \\
\text { second language construction learning. }\end{array}$ \\
\hline 38. & $\begin{array}{l}\text { Gordon, N. (2000). The acquisition of a second language. } \\
\text { European Journal of Paediatric Neurology, 4(1), 3-7. }\end{array}$ & $\begin{array}{l}\text { To explore the processes behind the } \\
\text { acquisition of second language. }\end{array}$ \\
\hline 39. & $\begin{array}{l}\text { Y1lmaz, S., \& Aslan, M. (2015). Parent-Child Interaction in } \\
\text { Language Acquisition and Personality Development of Young } \\
\text { Children in Monolingual and Bilingual Families. Euser Journal. }\end{array}$ & $\begin{array}{l}\text { To assess Parent-Child Interaction in } \\
\text { Language Acquisition and Personality } \\
\text { Development } \text { Young } \\
\text { Children in Monolingual and Bilingual } \\
\text { Families }\end{array}$ \\
\hline 40. & $\begin{array}{l}\text { Sakai, K. L. (2005). Language acquisition and brain } \\
\text { development. Science, 310(5749), 815-819. }\end{array}$ & $\begin{array}{l}\text { To explore the understanding and } \\
\text { representation of the "final stage" of } \\
\text { language acquisition in a mature brain. }\end{array}$ \\
\hline 41. & $\begin{array}{l}\text { Goriot, C., Broersma, M., McQueen, J. M., Unsworth, S., \& Van } \\
\text { Hout, R. (2018). Language balance and switching ability in } \\
\text { children acquiring English as a second language. Journal of } \\
\text { Experimental Child Psychology, 173, 168-186. }\end{array}$ & $\begin{array}{l}\text { To study the relative lexical proficiency of } \\
\text { L2 learning children with relation to } \\
\text { executive functioning. }\end{array}$ \\
\hline 42. & $\begin{array}{l}\text { Yusa, N., Koizumi, M., Kim, J., Kimura, N., Uchida, S., } \\
\text { Yokoyama, S., ... \& Hagiwara, H. (2011). Second-language instinct } \\
\text { and instruction effects: Nature and nurture in second-language } \\
\text { acquisition. Journal of Cognitive Neuroscience, 23(10), 2716-2730. }\end{array}$ & $\begin{array}{l}\text { To explore the effect of Nature vs Nurture in } \\
\text { Second Language Acquisition. }\end{array}$ \\
\hline
\end{tabular}




\begin{tabular}{|c|c|c|}
\hline 43. & $\begin{array}{l}\text { Sorace, A., \& Serratrice, L. (2009). Internal and external interfaces } \\
\text { in bilingual language development: Beyond structural } \\
\text { overlap. International Journal of Bilingualism, 13(2), 195-210. }\end{array}$ & $\begin{array}{l}\text { To study the interface between syntax and } \\
\text { discourse pragmatics/semantics in bilingual } \\
\text { speakers. }\end{array}$ \\
\hline 44. & $\begin{array}{l}\text { Winsler, A., Díaz, R. M., Espinosa, L., \& RodrÃguez, J. L. (1999). } \\
\text { When learning a second language does not mean losing the first: } \\
\text { Bilingual language development in low-income, Spanish-speaking } \\
\text { children attending bilingual preschool. Child development, 70(2), } \\
\text { 349-362. }\end{array}$ & $\begin{array}{l}\text { To discuss two investigations which } \\
\text { explored the bilingual language } \\
\text { development outcomes of comparable } \\
\text { groups of low-income, Spanish-speaking, } \\
\text { Mexican American children who either did } \\
\text { or did not attended a bilingual } \\
\text { (Spanish/English) preschool. Additionally, } \\
\text { to see whether learning a second language } \\
\text { created problems in retaining the first } \\
\text { language. }\end{array}$ \\
\hline 45. & $\begin{array}{l}\text { Hu, X., Ackermann, H., Martin, J. A., Erb, M., Winkler, S., \& } \\
\text { Reiterer, S. M. (2013). Language aptitude for pronunciation in } \\
\text { advanced second language (L2) learners: Behavioural predictors } \\
\text { and neural substrates. Brain and language, 127(3), 366-376. }\end{array}$ & $\begin{array}{l}\text { To investigate the behavioural and } \\
\text { neurobiological predictors of advance L2 } \\
\text { learning. }\end{array}$ \\
\hline 46. & $\begin{array}{l}\text { McMurray, B. (2016). Language at three timescales: The role of } \\
\text { real-time processes in language development and evolution. Topics } \\
\text { in cognitive science, } 8(2), 393-407 \text {. }\end{array}$ & $\begin{array}{l}\text { To study the role of selection pressure in } \\
\text { language evolution. }\end{array}$ \\
\hline 47. & $\begin{array}{l}\text { Méndez, L. I., Crais, E. R., \& Kainz, K. (2018). The impact of } \\
\text { individual differences on a bilingual vocabulary approach for } \\
\text { Latino preschoolers. Journal of Speech, Language, and Hearing } \\
\text { Research,61(4), 897-909. }\end{array}$ & $\begin{array}{l}\text { To study the effect of individual differences } \\
\text { in culturally and linguistically responsive } \\
\text { (CLR) instructions. }\end{array}$ \\
\hline 48. & $\begin{array}{l}\text { Kaufman, S. B., DeYoung, C. G., Gray, J. R., Jiménez, L., Brown, } \\
\text { J., \& Mackintosh, N. (2010). Implicit learning as an } \\
\text { ability. Cognition, 116(3), 321-340. }\end{array}$ & $\begin{array}{l}\text { To study the impact of individual } \\
\text { differences in implicit learning with respect } \\
\text { to various cognitive and personality } \\
\text { variables. }\end{array}$ \\
\hline 49. & $\begin{array}{l}\text { Hassanzadeh, V., Gholami, R., Allahyar, N., \& Noordin, N. (2012). } \\
\text { Motivation and Personality Traits of TESL Postgraduate Students } \\
\text { towards the Use of Information and Communications Technology } \\
\text { (ICT) in Second Language Teaching. English Language } \\
\text { Teaching, 5(4), 74-86. }\end{array}$ & $\begin{array}{l}\text { To see the effect of motivation and } \\
\text { personality traits towards the use of } \\
\text { information and communication technology } \\
\text { in second language teaching. }\end{array}$ \\
\hline 50. & $\begin{array}{l}\text { Biedroń, A. (2011). Personality factors as predictors of foreign } \\
\text { language aptitude. Studies in Second Language Learning and } \\
\text { Teaching, 1(4), 467-489. }\end{array}$ & $\begin{array}{l}\text { To examine the level of big five factors in } \\
\text { two groups of learners: gifted and non- } \\
\text { gifted. and to test whether personality traits } \\
\text { are predictors of foreign language aptitude } \\
\text { as measured by two foreign language tests. }\end{array}$ \\
\hline 51. & $\begin{array}{l}\text { Ozanska-Ponikwia, K., \& Dewaele, J. M. (2012). Personality and } \\
\text { L2 use: The advantage of being openminded and self-confident in } \\
\text { an immigration context. Eurosla Yearbook, 12(1), 112-134. }\end{array}$ & $\begin{array}{l}\text { To assess personality and L2 use: The } \\
\text { advantage of being open-minded and self- } \\
\text { confident in an immigration context. }\end{array}$ \\
\hline 52. & $\begin{array}{l}\text { Frost, R., Siegelman, N., Narkiss, A., \& Afek, L. (2013). What } \\
\text { predicts successful literacy acquisition in a second }\end{array}$ & $\begin{array}{l}\text { To study whether success of failure in the } \\
\text { assimilation of the structure of L2 can be }\end{array}$ \\
\hline
\end{tabular}




\begin{tabular}{|c|c|c|}
\hline & language? Psychological science, 24(7), 1243-1252. & predicted by non-linguistic learning abilities. \\
\hline 53. & $\begin{array}{l}\text { Slevc, L. R., \& Miyake, A. (2006). Individual differences in } \\
\text { second-language proficiency: Does musical ability } \\
\text { matter? Psychological science, 17(8), 675-681. }\end{array}$ & $\begin{array}{l}\text { To examine the relation between musical } \\
\text { ability and second-language (L2) } \\
\text { proficiency in adult learners. }\end{array}$ \\
\hline 54. & $\begin{array}{l}\text { Pellegrini, A. D., Galda, L., Flor, D., Bartini, M., \& Charak, D. } \\
\text { (1997). Close relationships, individual differences, and early } \\
\text { literacy learning. Journal of experimental child psychology, 67(3), } \\
\text { 409-422. }\end{array}$ & $\begin{array}{l}\text { To study the role of emotional investment } \\
\text { and mutuality characteristic of friendship } \\
\text { dyads on emotions and literature language } \\
\text { with respect to conflict and resolution. }\end{array}$ \\
\hline 55. & $\begin{array}{l}\text { Azadipour, S. (2019). Personality types and intercultural } \\
\text { competence of foreign language learners in education } \\
\text { context. Journal of Education and Health Promotion, } 8 \text {. }\end{array}$ & $\begin{array}{l}\text { To study the role of personality types on } \\
\text { learner's competency in the intercultural } \\
\text { context. }\end{array}$ \\
\hline 56. & $\begin{array}{l}\text { Golestani, N., \& Zatorre, R. J. (2009). Individual differences in the } \\
\text { acquisition of second language phonology. Brain and } \\
\text { language, 109(2-3), 55-67. }\end{array}$ & $\begin{array}{l}\text { To study the role of individual differences in } \\
\text { the acquisition of L2 sound-learning } \\
\text { (phonology). }\end{array}$ \\
\hline 57. & $\begin{array}{l}\text { MacIntyre, P. D. (1995). How does anxiety affect second language } \\
\text { learning? A reply to Sparks and Ganschow. The modern language } \\
\text { journal, 79(1), 90-99. }\end{array}$ & $\begin{array}{l}\text { To demonstrate that language anxiety can } \\
\text { influence language learning by describing } \\
\text { the processes that are believed to underlie its } \\
\text { effects. }\end{array}$ \\
\hline 58. & $\begin{array}{l}\text { Kormos, J. (2012). The role of individual differences in L2 } \\
\text { writing. Journal of second language writing, 21(4), 390-403. }\end{array}$ & $\begin{array}{l}\text { To review the most important individual } \\
\text { difference factors that might explain } \\
\text { variations in L2 writing processes and } \\
\text { discuss the influence of these factors on how } \\
\text { L2 learners exploit the language learning } \\
\text { potential of writing tasks. }\end{array}$ \\
\hline 59. & $\begin{array}{l}\text { Taguchi, N. (2014). Personality and development of second } \\
\text { language pragmatic competence. Asian EFL Journal, 16(2), 203- } \\
221 \text {. }\end{array}$ & $\begin{array}{l}\text { To examine the effect of personality on the } \\
\text { development of pragmatic competence } \\
\text { among second language (L2) learners of } \\
\text { English. }\end{array}$ \\
\hline 60. & $\begin{array}{l}\text { Bernat, E., Carter, N., \& Hall, D. (2009). Beliefs about language } \\
\text { learning: Exploring links to personality traits. University of Sydney } \\
\text { Papers in TESOL, 4(4). }\end{array}$ & $\begin{array}{l}\text { To study beliefs about language learning: } \\
\text { Exploring links to personality traits. }\end{array}$ \\
\hline
\end{tabular}

\section{Findings:}

Individual differences (I.Ds) state that every individual is unique and possess their own unique patterns of behaviour, feelings and cognition that differ from one individual to another. Personality traits, levels of motivation, perceptions of self all differ from one individual to another and this determines why one engages in the SLL process and how they perform. With respect to all the language learners, it is evident that some 
Running Head : A SYSTEMATIC REVIEW ON SECOND LANGUAGE ACQUISITION

individuals are high performers in terms of L2 while some are low performers. Researches show that there exist differences in terms of approach to SLL process between high performers and low performers. A study done by Polat (2013) reported that high performers (H.Ps.) express their love for SLA more than the low performers (L.Ps.), i.e. H.Ps. can identify the specific portions for improvement in their L2 learning while L.Ps. speak about general improvement development, and how H.Ps. concentrate more on the meaning of the whole sentence while L.Ps. focus more on the meaning of individual words. This suggests that there is no doubt that H.Ps. put in more effort, feelings and introspection into their SLA process.

\section{Perception towards acquisition and learning of a language based on one's personality}

The first point to be understood is to determine the fine line between the words acquisition and learning. Language acquisition is a subconscious process while the learning is a conscious one. There is a phenomenon called the phenomenon of "switch mechanism" which allows individuals to switch from one language to another. There lies a difference in brain areas when L2 is acquired in adulthood and in childhood. However, when L2 is acquired early in life, they both tend to be in the same region of frontal lobes. Bilingual children were also stated to be more advanced in their learning systems because of learning two symbols of languages at an early age (Gordon, 2000).

Some personality traits make some individuals eager to learn more, perceive the language well and show acceptance towards others who speak that language, they want to interact, form groups and learn more about the culture, some studies have yielded results consistent to what we state here. Personality traits and attitudes toward foreign language learning (FLL) have been reported innumerable times to have a positive relationship. Additional discussions on this will be done under the next heading.

Even in the cases of immigrants in a research study (Ozanska-Ponikwia \& Dewaele, 2012), those who scored high on Openness to Experience and Self-esteem domains were more likely to seek authentic interaction 
Running Head : A SYSTEMATIC REVIEW ON SECOND LANGUAGE ACQUISITION

in the L2, driven by a genuine desire to find out more about the L2 language and the associated culture. These explorers of the unfamiliar, these curious, creative, original, imaginative, self-confident individuals may gradually build a large network of L2 interlocutors, which may aid in speeding up their L2 socialization process and contribute to the development of their L2. Openness thus emerges as the most important personality trait underlying the individual differences in L2 development and L2 use among immigrants. Reciprocal causation might also explain the increased use and confidence in the L2, as immigrants may perceive a need to be more extroverts, open-minded, agreeable and empathic in order to function properly in their new environment. This may in turn increase their proficiency, their self-confidence and their willingness to learn L2.

When it comes to the perception of oneself, the language learning and others who are speaking the same language or trying to learn it, many studies have shown some positive relations. A study showed that Japanese students were willing to actively seek and learn English like native speakers (individual differences play a huge role here) (Nakamura, 2019). This study reports how they find it a positive act for themselves and others. They see it as great career opportunity. But also, they wish to maintain their identity as Japanese and are unwilling to change it. Studies on Japanese students have also related the concept of self-image and certain life domains with SLA, where some saw their ideal self as being able to speak certain Honorifics of the language while others wish to see themselves as masters in understanding or replicating pop songs. This suggests that certain mental representations of L2 self-image may be linked to certain activities such as being able to communicate properly in interpersonal relationships or in professional relationships or in leisure time.

When it comes to perception abilities while speaking an L2, differences have been noted among native speakers (NS) and non-native speakers (NNS). Perceptions of emails, standards of politeness have been a predictor of this difference (Economidou-Kogetsidis, 2016). It is often reported in the researches that NNS come off as rude or ignorant to the NS even if the intention of the NNS was not so. This misperception can be 
Running Head : A SYSTEMATIC REVIEW ON SECOND LANGUAGE ACQUISITION

attributed to the differences in the usage and understanding semantic structures of the language learned by NNS and the language already known by NS. NNS are often not familiar with colloquial tone of the language and this may further complicate interactions between NS and NNS.

All these suggest that when individuals learn or acquire a new language, some perceive it as a chore or a burdening task that may result in them being low performers while others may perceive it as fun and an intellectually stimulating activity that may result in them being high performers of that language. The concepts of self-esteem and self-confidence are of importance here as they not only facilitate the SLA process but are also derived from it.

\section{Personality Factors Impact SLA and vice-versa}

Up until recent times, it was speculated that personality of an individual remains unchanged through adulthood. However, with recent researches into the personality domain, this notion was challenged and proved wrong time and time again. Of all the factors for personality change beyond adulthood, second SLL or second language acquisition (SLA) has been recently tested to account for the said personality change. The most dominant personality traits taxonomy is the Five Factor Model that consists of Openness to Experience, Conscientiousness, Agreeableness, Extraversion and Neuroticism. Although there are higher-order and lowerorder trait systems according to other theories, its relation to SLA isn't too well discovered as of yet. Additionally, most of the researches in the SLA domain have been done with respect to motivation and aptitude, some researches point out the role of personality traits to either be a predictor to personality change or be facilitated by certain personality traits.

Personality traits give rise to individual differences (IDs) and account for different social attitudes (Lalonde \& Gardner, 1984). Personality traits have been reported to be a potent factor in determining one's willingness to learn the language (Dewaele, 2012), willingness to communicate in that language (Machintyre \& 
Charos, 1996), motivation towards that language (Polat, 2013; Oroujlou \& Vahedi, 2011), and attitudes towards the learning situation (Lalonde \& Gardner, 1984). All the personality traits (as per OCEAN) have been consistently linked to SLA (Pourfeiz, 2015; Hu \& Reiterer, 2009; Hu et al., 2013; Obralic \& Mulalic, 2017). This suggests that individuals in the SLA process are more open to new experiences and treat the process of L2 learning as a fun challenge. These individuals do not hesitate to step out of their comfort zone of native language and explore the language systems that are beyond their native one. Furthermore, these individuals may come off as warm towards not only the L2 learning process but also towards others who are in the same boat as them. Thus, they are helpful and are more willing to interact with others.

With regards to the domains of extraversion and introversion, extroverts have been reported to be more likely the ones to initiate a conversation and initiate new topics of discussion in L2 (Abali, 2006). Introverted learners are more likely to be shy, be more anxious about their L2 learning process and have difficulties in initiating conversations or discussions in L2. Shyness, an individual's temperamental characteristic, has also been reported to lower L2 skills, e.g. the expressive and receptive language skills (Keller, Troesch and Grob, 2013). This results in the slower acquisition of L2 than others. Additionally, according to the Monitor Hypothesis by Krashen, extroverts are also "under-users", i.e. those L2 learners who prefer to not use their conscious knowledge while utilizing their L2 skills (Schutz, 1998).

To counter against the previous findings mentioned, Introverts can also be hypothesized to be better in the SLA because of their quiet, intuitive and observing nature. Acquisition is an unconscious process of learning that refers to internalizing the learning material. In this regard, introverts can prove to be the best learners as they may be logical and precise learners who are able to exercise judgment and relevant thoughts. However, it is better to not distinguish between introvert and extrovert learners as they both have different approaches to and strategies for the SLA. They both have their pros and cons with regards to SLA. 
Language learning or language acquisition process is a journey that has its progress moments and stagnant moments. Individuals high in conscientiousness are more likely to stay consistent and determined in a systematic manner that will facilitate the L2 learning process. Additionally, emotional stability has been reported to be negatively correlated to hesitation in the L2 learning process and language anxiety. Thus, being organized, being open and flexible, being accepting, and being in control of one's emotions are the potent personality traits that determine the success for learning or acquiring a language. These personality traits help individuals to use their specific strengths (i.e. cognitive abilities) to balance out or compensate for their specific weakness (e.g. language anxiety) during the SLA process.

The way individuals lay down their priorities with respect to L2 learning is relevant to investigate. Researches suggest that students who have a positive orientation towards their L2 are more likely to actively engage in the SLA process (LoCastro, 2001). It is so because these individuals perceive the importance of learning L2 and see connections with it with their future studies or career opportunities and in the $21^{\text {st }}$ century, knowing more than 2 languages is seen as having a competitive advantage in the global market of job sectors. Some researches have also been done on personality in terms of Myers-Briggs Inventory and they report Intuition and Sensing to be the dominant factors for the FLL students (Moody, 1988; Nikoopour, AminiFarsani, 2011).

Focusing on the neurobiological part of language learning, it has been shown that L2 learning results in the activation in certain brain functioning areas. Prolonged activation can result in the ultimate change in the brain functioning which might affect the personality of an individual. L2 acquisition is represented differentially in the cortical areas of the brain. The activation of the Interior Frontal Gyrus (IFG) is affected by the degree of exposure to a language (Yusa et al., 2011). This also suggests that there is no critical sensitive period for 
Running Head : A SYSTEMATIC REVIEW ON SECOND LANGUAGE ACQUISITION

acquiring a language because there is no sensitive period for having brain changes in an individual.

Acquisition of a language can occur at any stage of an individual's life.

Apart from the general population, studies done on immigrants have showed that they often have the tendency to over socialize and be more extroverted, open minded and agreeable than usual. As a result, they often show an increased use of L2 and higher self-confidence, making them willing and rapid learners who have an increased L2 proficiency (Asendorpf and Meier, 1993; Eurostat, 2011; Scheele, Leseman and Mayo, 2010).

\section{Motivation Impact SLA and vice-versa}

Learning a new language requires knowing and learning its phonology, pragmatics, semantics, etc. Practicing writing of the L2 may prove to be difficult at the beginning but it is an important process that contributes extensively to the SLA process. Motivational variables and self-regulatory capacity may interact with the individual's cognitive factors and may both affect the L2 writing processes such as planning, formulation, transcribing and editing what's written (Kormos, 2012).

Personality factors are important as they may be a predictor of an individual beginning or tackling the SLA process. Motivation is another factor that, coupled with appropriate personality traits, can serve as a facilitator for the SLA process. 8 personality variables studied by Lalonde and Gardner (1984) correlated significantly with Motivation, thereby, suggesting a link between personality and motivation. Attitudinal constructs were also reported to be casually linked to Motivation because social attitudes also serve a motivational purpose.

Motivation can be intrinsic (internally rewarding) or extrinsic (externally rewarding). Researches have reported that motivation combined with positive attitudes towards the SLA process plays an important role in enhancing one's language proficiency and efficiency. Successful language learning can be associated with motivation and the internal characteristics of the language learner such as positive task orientation, appropriate ego involvement, perseverance, need for achievement drive, tolerance for ambiguity, flow experiences, and goal 
orientation (Oroujilou and Vahedi, 2011). Motivation is also responsible for the frequency of L2 communication by the L2 learners. When one is engaged in SLA process that he/she finds valuable, he will automatically be motivated to stay engaged in such process. We can also attribute the flow experiences to the SLL process, whereby the "person's body or mind is stretched to its limits in a voluntary effort to accomplish something difficult and worthwhile" (Csikzentmihalyi, 1990). However, not every SLA process can be called flow experiences.

\section{Socio-cultural factors Impact SLA}

Some researches have suggested that personality factors do not account for the major determinants of an individual's linguistic abilities, rather it is the interplay between one's personality and their socio-cultural environment that determine the success of SLL (Stobbard, 1992). There is no denying that personality factors are potent in SLA process but as the bio-psycho-socio model suggests, any phenomenon can be described as the interplay between the 3 domains.

In the social context, teachers and instructors play an important role and so do their feedbacks (Lou and Noels, 2019). Communication is a process of understanding and transferring meaning. Effective communication is a two-way process of that. The communication becomes two-way when the receiver sends feedback to the sender. Likewise, teachers, whose primary role is to teach or introduce learning materials to the students, can also be the one who provides feedbacks in the forms of suggestions, criticisms or praises in accord to the learners' L2 performance. There are many communication barriers that may arise from the environment of from the individual himself. Among all the intra-individual barriers, "Hesitation" is one that is of most relevance here as hesitance also predicts one's willingness to communicate (Macintyre \& Blackie, 2012) in L2.

As the previous findings suggest, there is a strong correlation between emotions and SLA. Positive attitudes and emotions such as eagerness, warmth, willingness, etc may facilitate the SLA process while 
negative attitudes such as anger, sadness, frustration, boredom may hinder the SLA process. Students' better ability to control and regulate emotions also reflects their emotional intelligence (EQ) (Oz, Demirezen \& Pourfeiz, 2015). Because emotions play this strong of a role in the learning process, teachers and instructors should adopt strategies, policies, approaches and classroom activities that contribute to the betterment of students' EQ (Karim, Abidin \& Ali, 2016). Teachers' use of different Information and Communication Technology (ICTs) that include specialized software applications and simulations may not only motivate the students but also the teachers themselves (Hassanzadeh et al., 2012).

Researches have also identified several factors for students' engagement and willingness to communicate in L2 (Zarrinabadi, 2014). These factors identified are (a) teacher's wait time, i.e. the adequate silent pause between teacher's initiation and learner's response; (b) Teacher's decision of the topic of conversation; (c) Correction of errors the learners make during interaction; (d) Teacher's support and the creation of a supportive environment for the L2 learners to express themselves. Teacher's interactions with the students and peers' interactions can serve as potent factors under motivational strategies as well (Schwartz, Deeb \& Hijazy 2019).

Other forms of social environment that has an effect on the L2 learning and performance of the individuals are peer groups, parents and educational institutions. It is hypothesized that bilingual or multilingual school's rear bilingual or multilingual children who are reported to be more advanced in their learning systems because of learning two symbols of language at an early age (Gordon, 2000). This form of education is viewed both in the negative and positive light. On the negative side, it is stated that bilingual children may be put at a disadvantage because they tend to have a smaller vocabulary in each language than their monolingual counterparts. On the positive side, it is stated that bilingualism may have a positive side as it enhances children's cognitive and linguistic development and assimilates them into a different culture (Bialystok, 2006). 
Additionally, researches investigating the relationship between personality and culture with respect to SLA report that learning a new language implies the automatic representation of new cultural frames associated with that particular language (Veltkamp et al., 2013). This, in turn, provides the individual with a new range of perceiving and displaying his/her personality, thus, enhancing their own personal self. Even Stephan Krashen had propounded that every new language we acquire, we acquire a new personality along with it. Adding further, when we speak or switch languages, we bring out the personality that we created along with that language.

\section{Discussion}

The findings of the present study indicate every individual approaches the Second Language Acquisition Process (SLA) differently and has a different success rate with it, as everyone is unique in personality and behaviour. Also, people tend to express varying amounts of love and enthusiasm for their respective L2 and this further contributes to their overall performance (Polat, 2013). Consequently, we can say that when someone is acquiring or internalizing a new language, their performance may also be higher than those who are simply "learning" it. In that sense, a research study done by Polat (2013) shows that High Performers (H.Ps.) have less self-doubt and are hence more confident compared to Low Performers (L.Ps.), which further results in H.P's putting even more effort and feelings into their L2 learning process.

The motivations for L2 learning can be intrinsic (self-motivation) as well as extrinsic (externally rewarding). The major findings for the bi-directionality of personality and the SLA Process can be summarized as:

a. One of the main traits H.Ps. of L2 possesses that aids in SLA is Openness to Experience and a high selfesteem and self-confidence. These individuals are explorers of the unknown, gifted with innate curiosity, creativity and yearning to learn the new which speeds up their L2 Learning and Socialization Process. 
Consequently, as these individuals come to have a grip on their L2, their confidence and self-esteem levels increase thus resulting in these individuals acquiring a sense of mastery over the L2.

b. Individuals often grow a mental representation of L2 which they associate with either better communication skills in interpersonal relationships (e.g. - communication with friends or batchmates from a different linguistic background), and/or professional relationships (e.g. - job or study opportunities in different countries) and/or to leisure time activities (e.g. - wanting to replicate the lyrics of a song in a different language) (Nakamura, 2019). SLA process produces a different version of self known as the L2 self and this L2 self has its own way and colors of seeing the world. Thus, we can say that SLA process not only boosts one's L1 self-confidence and self-esteem but also gives rise to one's L2 self-concept. Furthermore, this L2 self-concept is constantly reinforced negatively or positively by the L2 learning experiences and this L2 self-concept also directs how the L2 learning will progress.

c. Motivation levels, which are not personality traits by themselves but largely influence them to a large extent, also affect the SLA process. The novelty, complexity and appropriate challenging atmosphere created by L2 learning process motivates an individual (either intrinsically or extrinsically) to begin or stay engaged in the L2 learning process. Additionally, the progress that one makes or the rewards (either internal or external) that one gets helps to alleviate or sustain these motivation levels to keep learning the L2. This is also consistent with other studies that have focused on motivation levels and SLA process (Lalonde \& Gardner; Kormos, 2012; Oroujilou and Vahedi, 2011). This is also consistent with the Input Hypothesis by Stephen Krashen (Schutz, 2018).

d. The perception of SLA process is also important to note. One might either view it as a burdensome task or one might view it as a creative challenge. This perception will determine one's approach towards the SLA process. Furthermore, when speaking about perception, as stated earlier SLA gives rise to a new self - the L2 self. SLA processes also play a role in how one views themselves (if they are meeting their 
goals, doing their tasks properly, etc), how one views others (if they are helpful, friendly or cold) and how one views the world and culture in the L2 language. The perception also refers to how others (e.g. Native Speakers or NS) see these L2 learning individuals (i.e. the Non-Native speakers). Many at times, it can be seen that NNS are often unaware of the colloquial tones or nuances of the language which might make them appear too formal or even rude to the NS (Economidou-Kogetidis, 2016).

e. Apart from I.Ds and personality traits, a research study has also shown music to aid in the phonological acquisition of L2. It is hypothesized that music and melodious sounds may facilitate the ability to analyze sound structure of the novel phonological structure of L2 (Slevc and Miyake, 2006).

Based on the findings and discussions on this topic, we propose a model that portrays the bi-directional relationship of SLA with personality traits with respect to other psycho-socio-cultural variables' influence over the two. 


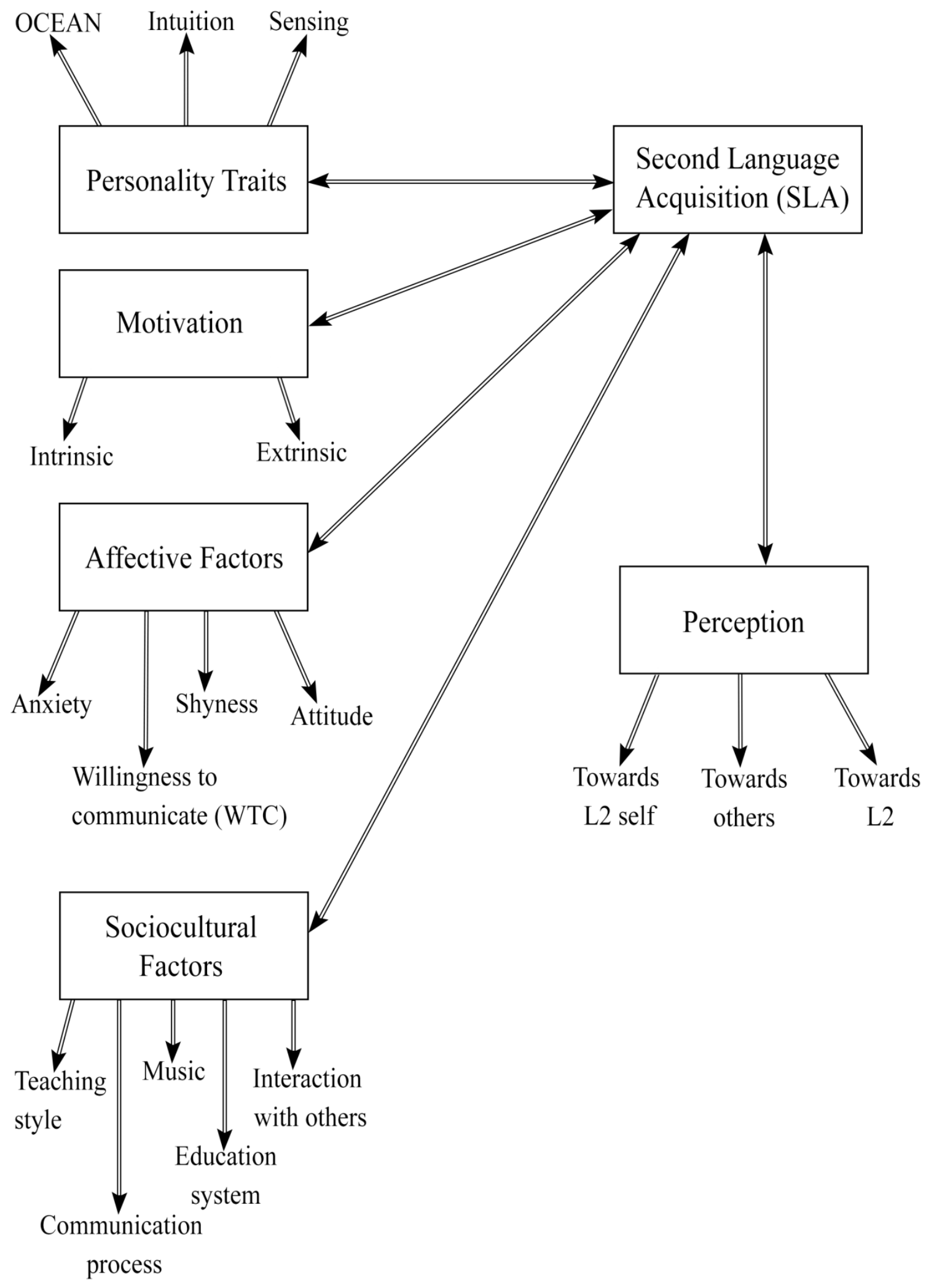

Proposed model of Bidirectional Relationship between Personality Traits and SLA with associated psycho-socio-cultural factors. 
Through this model we try to show all the factors that help in acquiring an L2. The factors put up in the diagram were shown to have influenced SLA with different dimensions. Numerous researches have established the influence of Personality traits in SLA. Personality traits given by Paul Costa and Robert McCrae (1980s) in OCEAN have been consistently linked to SLA (Hu \& Reiterer, 2009; Obralic \& Mulalic, 2017; Pourfeiz, 2015). They also facilitate in determining one's willingness to learn the language (Dewaele, 2012) and willingness to communicate (WTC) in that language (Machintyre \& Charos, 1996). Motivation has been researched with reference to SLA. Lalonde and Gardner (1984) study on personality variables, has correlated with motivation providing a link between motivation and personality. Successful language learning can be associated with motivation and the internal characteristics of the language learner (Oroujilou and Vahedi, 2011).

Affective factors include anxiety, WTC, shyness and attitude. Macintyre (1995) showed how divided attention and anxiety hampers language learning and performance. Supportive teaching environment, focus on students' knowledge and choices have increased willingness to communicate. Shyness as a factor has detrimental effects on L2 (Larissa, Troesch and Grob, 2013). Lalonde and Gardner (1984) have also showed that personality causes social attitudes and attitudes, and they are linked to motivation which in turn influences SLA. (Lou and Noels, 2019) have studied how teachers, instructors and their feedback influence SLA. Skills like musical abilities have positive impact too (Miyake and Slevc, 2006). Furthermore, when it comes to interaction with others, Macintyre \& Blackie (2012) have reported "hesitation" to be affecting WTC.

Emotions play a strong role in the learning process, teachers and instructors should adopt strategies, policies, approaches and classroom activities that facilitate better learning process and enhance the learning experience and EQ (Abd et al., 2016). Perception varies greatly. Researchers have suggested that native and non-native speaker have different ideas about perception, being it politeness, rudeness (Economidou-Kogetsidis, 
2016). Furthermore, studies have showed that L2 self-image may influence ability to communicate and willingness to indulge in the language learning.

Altogether this suggests that all these factors combined together will affect SLA and language learning. The intensity may vary from individual to individual, but together these factors will facilitate or not facilitate the SLA process.

\section{Limitations and Future Research}

This study was done completely on the basis literature review of a target population of some available researches. Thus, this study was limited to the theoretical domains. We encourage more tests to be done to quantitatively explore the relationship between personality traits and SLA. Further future directions recommended by us are:

1) Many researches have been done on second language motivation with primary focus being on the language

English. However, in order to understand more on the topic, future investigation must be done in context of languages other than English.

2) Much of the researches done so far in the domain of personality and SLA was done by using the Five Factor Model by Paul Costa and Robert McCrae in the 1980s. In order to get a comprehensive understanding about the relationship between personality traits and SLA, we suggest researchers to explore the relationship of 'Higher Order Traits' and 'Lower Order Traits' with SLA process. 
Running Head : A SYSTEMATIC REVIEW ON SECOND LANGUAGE ACQUISITION

\section{Conclusion}

The current paper discussed the relationship of personality traits with second language acquisition (SLA). We state the bi-directionality of the relationship between personality traits, and motivation levels with SLA process. As detailed in the paper, a number of personality traits seem to influence the L2 learning process of an individual - the most noteworthy of them being one's own curiosity and motive. L2 learning is also influenced by the fact that whether an individual is an introvert or an extrovert.

Additionally, it can be inferred that from the aforementioned points is that SLA is mainly a matter of perception i.e., it is dependent on how an individual choses to view it. Some may perceive it as a chore or a cumbersome task that may result in them being low performers while others may perceive it as a new experience and an intellectually stimulating activity that often results in them being high performers.

The $21^{\text {st }}$ century brings along with it its needs to know multiple languages. It has been observed in the educational system (especially monolingual educational systems) that students and/or professors do not take the SLL process seriously. They have a misconception that knowing an L2 is of no further use outside of the exam purposes of L2. This discourages and further serves as a demotivating factor in the SLA process. To overcome this, we would recommend the professors to make use of and incorporate language games and activities that are intellectually stimulating and engaging in nature. We would suggest taking the FLL class as a recreation class to explore the language, culture the other selves and the other world in terms of L2. Apart from I.Ds and personality traits, some additional skills have also been reported to have facilitated in the phonological acquisition of L2 and one of them is musical ability.

Lastly, we have also discussed about the impact of socio-cultural variables on the SLA process, describing about the role of teachers, instructors and the importance of the communication process when it comes to SLA. We have also stated future directions for future researches to explore. 
Running Head : A SYSTEMATIC REVIEW ON SECOND LANGUAGE ACQUISITION

In further, through extensive researches done in this field, if these points are taken into consideration, we can ensure that it may appeal to a larger audience with different personality traits (as per OCEAN) and may aid in them acquiring the language and not just learning it.

\section{References}

- Abal1, F. (2006). The effect of personality traits extroversion/introversion on verbal and interactive behaviors of learners (Doctoral dissertation, Bilkent University). URL: http://hdl.handle.net/11693/29927

- Asendorpf, J. B., \& Meier, G. H. (1993). Personality effects on children's speech in everyday life: Sociability-mediated exposure and shyness-mediated reactivity to social situations. Journal of personality and social psychology, 64(6), 1072. DOI: https://doi.org/10.1037/0022-3514.64.6.1072

- Bialystok, E. (2006). Second-language acquisition and bilingualism at an early age and the impact on early cognitive development. Encyclopedia on early childhood development, 1-4. DOI: https://doi.org/ 10.1.1.833.8531

- Coker, C., \& Mihai, F. (2016, August 11). Personality Traits and Second Language

Acquisition: The Influence of the Enneagram on Adult ESOL Students. DOI: https://doi.org/10.1002/tesj.281 
- Cook, V. (1996). Second language learning and second language teaching (2 ${ }^{\text {nd }}$ ed.). New York: Arnold.

- Csikszentmihalyi, M., \& Csikzentmihaly, M. (1990). Flow: The psychology of optimal experience (Vol. 1990). New York: Harper \& Row. DOI: $\quad$ https://doi.org/10.1080/00222216.1992.11969876

- Dewaele, J. (2012, November 05). Personality in Second Language Acquisition. The Encyclopaedia of applied Linguistics. DOI: https://doi.org/10.1002/9781405198431.wbeal0904

- Dörnyei, Z. (2006, January 01). Individual differences in second language acquisition. DOI: https://doi.org/10.1075/aila.19.05dor

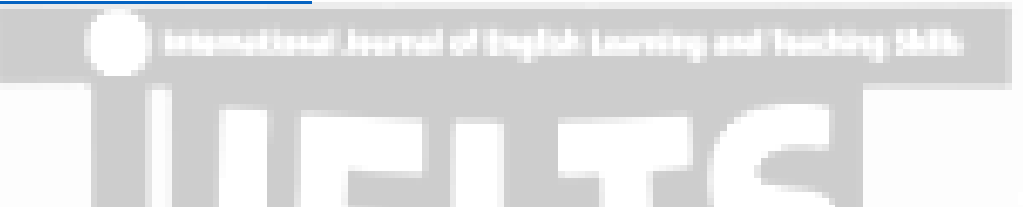

- Economidou-Kogetsidis, M. (2016, October 22). Variation in evaluations of the (im)politeness of emails from L2 learners and perceptions of the personality of their senders. Journal of Pragmatic. DOI: https://doi.org/10.1016/j.pragma.2016.10.00

- Elizabeth, P. P. (2009). Bilingualism. Retrieved from: https://www.britannica.com/topic/bilingualism.

- EUROSTAT. (2011). Migrants in Europe: A statistical portrait of the first and the second generation. Retrieved from: https://ec.europa.eu/eurostat/documents/3217494/5727749/KS-31-10-539-EN.PDF 
- Ferenhof, H. A., \& Fernandes, R. F. (2016). Desmistificando a revisão de literatura como base para redação científica: método SSF. Revista ACB, 21(3), 550-563. URL:

https://www.researchgate.net/publication/325070845

- Gass, S., \& Selinker, L. (1994). Second language acquisition: An introductory course.

Hillsdale, NJ: Lawrence Erlbaum. DOI: https://doi.org/10.1017/S0022226700016844

- Gayle, G. M. H. (1981). Personality, Motivation, and Second Language Learning. $\quad$ Canadian Journal of Education / Revue Canadienne de L'éducation, 6(3), 55. DOI: 10.2307/1494655

- Gordon, N. (2002, May 25). The acquisition of a second language. European Journal of Paediatric Neurology, 4(1), 3-7. DOI: https://doi.org/10.1053/ejpn.1999.0253

- Hassanzadeh, V., Gholami, R., Allahyar, N., \& Noordin, N. (2012). Motivation and Personality Traits of TESL Postgraduate Students towards the Use of Information and Communications Technology (ICT) in Second Language Teaching. English $\quad$ Language Teaching, 5(4), 74-86. URL: https://eric.ed.gov/?id=EJ1079051

- Hill, J., \& Miller, K. B. (2013). Classroom instruction that works with English language learners. ASCD. 
- Hu, X., Ackermann, H., Martin, J. A., Erb, M., Winkler, S., \& Reiterer, S. M. (2013). $\quad$ Language aptitude for pronunciation in advanced second language (L2) learners: Behavioural predictors and neural substrates. Brain and language, 127(3), 366-376. DOI:

https://doi.org/10.1016/j.bandl.2012.11.006

- Hu, X., \& Reiterer, S. (2009). Personality and pronunciation talent in second language acquisition. Language talent and brain activity, 97-130. URL:

https://www.researchgate.net/publication/285856473

- Karim, N. A., Abidin, D. Z., \& Ali, S. N. D. M. PERSONALITY FACTORS AND SECOND

LANGUAGE ACQUISITION: AN ISLAMIC VIEWPOINT. URL:

https://pdfs.semanticscholar.org/d258/2b91519ee4fd1a9b786476375b66110213f2.pdf

- Keller, K., Troesch, L., \& Grob, A. (2013, September 19). Shyness as a risk factor for second language acquisition of immigrant pre-schoolers. Journal of applied developmental psychology, 34(6), 328-335. DOI: $\underline{\text { https://doi.org/10.1016/j.appdev.2013.07.001 }}$

- Kezwer, P. (1987). The Extroverted Vs. the Introverted Personality and Second Language Learning. TESL Canada Journal, 45-48. DOI: https://doi.org/10.1016/j.appdev.2013.07.001

- Kormos, J. (2012, November 01). The role of individual differences in L2 writing. Journal of second language writing, 21(4), 390-403. DOI: https://doi.org/10.1016/j.jslw.2012.09.003 
- Lalonde, R., \& Gardner, R. (1984). Investigating a causal model of second language acquisition: Where does personality fit? Canadian Journal of Behavioural Science/ Revue canadienne des sciences du comportement, 16(3), 224. DOI: https://doi.org/10.1037/h0080844

- Lanning, K., Pauletti, R. E., King, L. A., \& McAdams, D. P. (2018). Personality development through natural language. Nature human behaviour, 2(5), 327-334. DOI: https://doi.org/10.1038/s41562-018$\underline{0329-0}$

- Larsen-Freeman, D., \& Long, M. (1991). An introduction to second language acquisition research. London: Longman. DOI: https://doi.org/10.2307/3587466

- Lightbown, P.M., and Spada, N. (2013). How Languages Are Learned. Oxford: Oxford University Press.Print. URL:

http://tailieudientu.Irc.tnu.edu.vn/Upload/Collection/brief/Brief_72938_20190104090338_20181129150 620-Howlanguagesarelearned.pdf

- LoCastro, V. (2001, February 02). Individual differences in second language acquisition: Attitudes, learner subjectivity, and L2 pragmatic norms. System, 29(1), 69-89.DOI: https://doi.o

- ust 28). Promoting growth in foreign and second language education: A research agenda for mindsets in language learning and teaching. System, 86, 102126. DOI: https://doi.org/10.1016/j.system.2019.102126 
- Macaro, E. (2010). Continuum Companion to Second Language Acquisition. London: Continuum. Print.

- Mahmoodi, M., \& Moazam, I. (2014, June 10). Willingness to Communicate (WTC) and L2 Achievement: The Case of Arabic Language Learners. DOI: https://doi.org/10.1016/j.sbspro.2014.03.518

- MacIntyre, P.D, \& Blackie, R. (2012, November 03). Action control, motivated strategies, and integrative motivation as predictors of language learning affect and the intention to continue learning French. System, 40(4), 533-543. DOI: https://doi.org/10.1016/j.system.2012.10.014

- MacIntyre, P.D. \& Charos, C. (1994, June 01). Personality, Attitudes, and Affect as Predictors of Second Language Communication - Peter D. MacIntyre, Catherine Charos, 1996. Journal of language and social psychology, 15(1), 3-26. DOI: https://doi.org/10.1177/0261927X960151001

- Moody, R. (1988). Personality preferences and foreign language learning. The modern language journal, 72(4), 389-401. DOI: 10.2307/327751

- Nakamura, T. (2019, March 24). Understanding motivation for learning languages other than English: Life domains of L2 self. System, 82, 111-121. DOI: https://doi.org/10.1016/j.system.2019.03.006 
- Nikoopour, J., \& Amini Farsani, M. (2011, February 01). On the Relationship between Language Learning Strategies and Personality Types among Iranian EFL Learners. Journal of English studies, 1(1), 81-101. URL: http://jes.srbiau.ac.ir/article 5623 0.html

- Obralic, N., \& Mulalic, A. (2017). Correlation between personality traits and Language Learning Strategies among IUS Students. Journal of Applied Linguistics and Language Research, 4(5), 76-

84. URL: http://www.jilanaeini.ir/wp-content/uploads/2020/01/Correlation-between-Personality-Traitsand-Language.pdf

- Oroujlou, N., \& Vahedi, M. (2011, December 17). Motivation, attitude, and language learning.

Procedia-Social and Behavioral Sciences, 29, 994-1000. DOI: https://doi.org/10.1016/j.sbspro.2011.11.333

- Oz, H., Demirezen, M., \& Pourfeiz, J. (2015, May 31). Emotional Intelligence and Attitudes Towards Foreign Language Learning: Pursuit of Relevance and Implications. Procedia-Social and Behavioral Sciences, 186(0). DOI: https://doi.org/10.1016/j.sbspro.2015.04.118

- Ożańska-Ponikwia, K., \& Dewaele, J. (2012, January 01). Personality and L2 use: The advantage of being openminded and self-confident in an immigration context. Eurosla Yearbook, 12(1), 112-134. DOI: https://doi.org/10.1075/eurosla.12.07oza 
- Paradis, J. (2007). Second language acquisition in childhood. DOI:

https://doi.org/10.1002/9780470757833.ch19

○ Penfield, W. (1965). Conditioning the uncommitted cortex for language learning. Brain, 88(4), 787-798. DOI: https://doi.org/10.1093/brain/88.4.787

- Polat, B. (2013, February 15). Language experience interviews: What can they tell us about individual differences? System, 41(1), 70-83. DOI: https://doi.org/10.1016/j.system.2013.01.021

- Pourfeiz, J. (2015, May 31). Exploring the Relationship between Global Personality Traits and Attitudes toward Foreign Language Learning. Procedia-Social and Behavioral Sciences, 186, 467-473. DOI: https://doi.org/10.1016/j.sbspro.2015.04.119

- Robinson, D., Gabriel, N., \& Katchan, O. (2002, May 28). Personality and second language learning. DOI: https://doi.org/10.1016/0191-8869(94)90118-X

- Saul, M. (2017). Theories of Personality. Retrieved from: https://www.simplypsychology.org/personality-theories.html 
- Scheele, A. F., Leseman, P. P., \& Mayo, A. Y. (2010). The home language environment of monolingual and bilingual children and their language proficiency. Applied Psycholinguistics, 31(1), 117-140. DOI: 10.1017/S0142716409990191

- Schutz, R. R. (1998). Stephen Krashen's Theory of Second Language Acquisition. Retrieved from: https://www.sk.com.br/sk-krash-english.html.

- Schwartz, M., Deeb, I., \& Hijazy, S. (2019, June 01). “Say 'What happened?' in Hebrew. He does not speak Arabic!" Early language awareness as expressed in verbal and nonverbal interactions in the preschool bilingual classroom. DOI: https://doi.org/10.1016/j.linged.2019.05.001

- Slevc, L., \& Miyake, A (2006). Individual Differences in Second-Language Proficiency: Does Musical Ability Matter? - L. Robert Slevc, Akira Miyake, 2006. DOI: https://doi.org/10.1111/j.1467$\underline{9280.2006 .01765 . x}$

- Stobbart, C. L. (1992). Bilingualism: Theoretical perspectives of language diversity. South African Journal of Communication Disorders, 39(1), 13-23. URL: https://sajcd.org.za/index.php/sajcd/article/download/272/374

- Veltkamp, G., Conrads, M., Jacobs, A., \& Recio, G. (2012). Is personality modulated by language? - G. Marina Veltkamp, Guillermo Recio, Arthur M. Jacobs, Markus Conrad, 2013. DOI: 
- Yusa, N., Koizumi, M., Kim, J., Kimura, N., Uchida, S., Yokoyama, S., Hagiwara, H. (2011). Secondlanguage instinct and instruction effects: Nature and nurture in second-language acquisition. DOI: 10.1162/jocn.2011.21607

- Zarrinabadi, N. (2014, January 19). Communicating in a second language: Investigating the effect of teacher on learners' willingness to communicate. DOI: https://doi.org/10.1016/j.system.2013.12.014

- Zhang, Y. (2008). The Role of Personality in Second Language Acquisition. Asian Social Science. Vol. 4, No. 5 (2008). Pg. 58-59. 